\title{
Experts in Self-Isolation? Monastic Outreach during Lockdown
}

\author{
Richard D.G. Irvine
}

check for updates

Citation: Irvine, Richard D.G. 2021. Experts in Self-Isolation? Monastic Outreach during Lockdown. Religions 12: 814. https://doi.org/10.3390/ rel12100814

Academic Editors: Solange Lefebvre and Roberta Ricucci

Received: 13 July 2021

Accepted: 24 September 2021

Published: 27 September 2021

Publisher's Note: MDPI stays neutral with regard to jurisdictional claims in published maps and institutional affiliations.

Copyright: (C) 2021 by the author. Licensee MDPI, Basel, Switzerland. This article is an open access article distributed under the terms and conditions of the Creative Commons Attribution (CC BY) license (https:// creativecommons.org/licenses/by/ $4.0 /)$.
Department of Social Anthropology, University of St Andrews, St Andrews KY16 9AL, UK; rdgi@st-andrews.ac.uk

\begin{abstract}
This paper draws on digital ethnography to examine the experience of a Catholic English Benedictine monastery in the context of restrictions on religious gatherings during the global COVID-19 pandemic. As the monks expand their digital presence and social media involvement, it is their experience of social withdrawal and apparent expertise in self-isolation that provides the grounding for their public engagement. While Max Weber depicts the monk as a world-transcending "virtuoso", in a time of lockdown, this separation from the world provides a point of connection with the experience of wider society.
\end{abstract}

Keywords: COVID-19; lockdown; digital religion; monasticism; Benedictine

\section{Introduction}

Catholic monasteries are, in a fundamental sense, spaces of social distancing. Characterised as withdrawal from the wider world, monastic life ritualises separation through the boundedness of enclosure and the solitude of the monk's cell. Indeed, the way in which the architecture of the monastery spatially encompasses daily life expresses in material form an ideal of containment, providing space for living, praying, working, eating, and sleeping. Yet at the same time, monasteries exist in a relationship with wider society-a relationship which is both spiritual and economic. They may offer hospitality and spiritual direction, involve the lay public in religious services, and engage in pastoral, teaching, or other work in the wider community.

These relationships have been severely disrupted by the global COVID-19 pandemic and the measures taken to contain it. At the same time, the sense that those in monasteries might have a particular insight to offer in a time of lockdown creates new opportunities for monks and nuns to reach wider audiences with their experiences and potentially serve as exemplars. This paper focuses on the experience of an English Benedictine monastery which has previously been the focus of long-term ethnographic fieldwork (Irvine 2010, 2017), considering the ways in which the community responded to the suspension of public services and the closure of the monastery to visitors.

The focus of contemporary monastic life in the English Benedictine Congregation is living in community according to a daily timetable that structures public and private prayer, sacred reading (lectio divina), and work. Monks make vows of obedience (to the superior of the monastery, ordinarily an Abbot), stability (commitment to remain within that community), and conversatio morum (a phrase that resists straightforward translation and is generally understood as a commitment to live according to the norms of communal monastic life, as set out in the 6th Century Rule of St Benedict). It is within this context of life organized according to a fundamental principle to "work from home" — that is, a commitment to the monastery and its timetable - that monks saw themselves as having an understanding of the challenges and opportunities people faced when pandemic measures placed the population on lockdown. In fact, monks within English Benedictine monasteries do take on work which, in ordinary times, requires movement beyond the monastic enclosure and contact with people beyond the community, and in common with all the UK, they found this work disrupted. In particular, English Benedictine communities have 
historically served as parish priests, and also been involved with the running of Catholic private schools. It is worth nothing that in recent decades, there has been an increasing shift away from these forms of work. Laypeople now manage and teach throughout schools previously associated with English Benedictine monasteries. There has also been a reduction in the number of parishes beyond the locality of the monastery that the communities serve; this is partly a reflection of the reduced number of monks within the communities, but also part of a longer-term shift to place emphasis on the principal elements of monastic life within community living and the timetable of prayer, rather than external work for the instrumental purposes of the wider church. As such, monastic communities are recalibrating their relationships with the wider public through an increased emphasis on hospitality, welcoming visitors, sharing their public liturgical services, and sharing aspects of monastic spirituality that can be taken on in the lives of laypeople. The circumstances of lockdown therefore presented particular challenges for how the community could share their lives with the wider public and maintain these relationships.

Drawing on three months of digital ethnography-participating in online activities and events, following and engaging with the community's social media, and interviewing monks within the community about their experiences of lockdown-I look at the ways in which the community adapted during the lockdown, in particular through the expansion of their social media outreach and the development of new online activities. This article argues that the circumstances, although challenging for the monks, offered an opportunity for the community to present themselves as experts in social distancing; while at the same time enabling them to show their proximity to wider society, drawing lines of connection between their own lives as monks and the more general human experience.

The global COVID-19 pandemic has had a major impact on religious institutions and religious practice (Baker et al. 2020), with restrictions on gatherings changing the context and experience of participation in religious groups across the world (see e.g., Alyanak (2020) on Islam in Turkey; Kuipers et al. (forthcoming) on Islam in Indonesia; Cavaliere (2021) on Buddhism and Shinto in Japan; Ben-Lulu (forthcoming) on Reform Judaism in Israel; Chow and Kurlberg (2020) on Christian churches in Hong Kong, Singapore, the UK, and Sweden). Digital media has been a source of continuity of practice-enabling communities to continue meeting together and allowing continued participation from home-as well as ritual innovation (O'Brien 2020). The need for religious congregations to rapidly adapt to a digital environment has been characterised as a disruption of the religious marketplace (Frederick 2020), with the potential to bring about long-term reconfigurations of how people engage with religion, accelerating a virtual "new normal" (Norman and Reiss 2020) in place of face-to-face gatherings.

This loss of physical co-presence might be considered a vector for the further individualisation and privatization of religious practice (Rüpke 2016). Yet in the context of the pandemic, adaptation to new digital forms has had the potential to counteract social disconnection, providing "contexts for meaningful human connection that stems the tide of isolationism precipitated by quarantine" (Frederick 2020, p. 188).

The sudden need to find online alternatives to physical interaction "offers a space in which novel adaptations of ritual, prayer, and community may emerge" ( $\mathrm{O}^{\prime}$ Brien 2020, p. 244). This was a moment in which digital religion became ubiquitous out of necessity, though of course such experiments in online community and religious outreach have a longer history (Campbell 2010; Hutchings 2017). Monastic communities in particular have turned to digital outreach and social media to offer "a new visibility and incarnation" (Jonveaux 2013, p. 105) and a new route of evangelization, self-consciously counteracting the assumption that monks and nuns are, by their nature, outside modernity. As Jonveaux (2019) points out, the internet reflects and intensifies the complex dynamics of interaction between the monastery and the wider world. In the Benedictine context, where monks vow stability within their community, online communication can reinforce this commitment to place-making certain forms of communication possible without leaving the grounds of the monastery, and yet, at the same time, roaming online can be a new form of instability. 
There are clearly new possibilities for pastoral outreach, but will these undermine monastic separation and solitude, bringing the perpetual interactions and influences of the secular world inside the monastic enclosure?

Jonveaux (2019) makes clear that, despite the apparent novelty of the digital medium, these are manifestations of longstanding processes of negotiation in monastic communities. A key concern in the study of monasticism-explored at length by Weber (1968) in the posthumously published Economy and Society - is precisely the nature of the interactions that emerge between monastic communities and a wider laity who look to the 'virtuosic' example of the monks and for whose welfare much of the work of monasteries has historically been directed. The virtuoso, according to Weber (1963, pp. 151-65), is someone recognised as having a particular talent (in this case, for prayer and living the religious life), who combines this with the intensive practice required to cultivate this talent (see also Goldman and Pfaff 2014). This virtuosity, both by its exceptional nature and by the time, resources, and opportunity required to dedicate one's life to it, sets the specialist apart from the general population; and in particular, as Weber (1963, pp. 162-63) implies, it is usually developed through separation from the secular world. Yet this virtuosity attracts a wider public who look to the expert to provide specific services and to serve as a source of inspiration and example. In particular, we see a potential tension between the role of monasteries as a site for the spiritual salvation of their individual members, and their external focus for the benefit of the wider Church as a source of religious service to the world (Weber 1968, pp. 1166-68), as well as the tension between monastic separation and the need to enter into economic transactions with the wider world, providing the material means for continuation of monastic life.

Here, the response of monasteries to the pandemic shines new light on what Silber (1995) calls the "virtuoso-society complex", generating new forms of engagement where the monks draw on their own experience of social distancing and separation to provide support for and build community with a wider public coming to terms with such selfisolation for the first time. As the monks expand their digital presence and social media involvement, it is precisely their experience of social withdrawal that provides the pretext and value for their engagement with the world at this moment. This paper provides a case study of this dynamic through an ethnographic engagement with the experience of an English Benedictine community during the first period of lockdown in the UK. My focus is on the ways in which the monks of Downside Abbey, a community in the South West of England, adapted their outreach across a range of social media: recordings of liturgical services uploaded onto Soundcloud and shared on Twitter, Facebook, and Instagram; talks and reflections, particularly on monastic life and its relevance during a time of lockdown, uploaded onto YouTube; and occasional live events such as Q\&A sessions and monthly prayer services broadcast on Facebook and YouTube. It is important to note here that my ethnographic focus was on the community itself, the material it produced and the context and rationale for this outreach. In this sense, what I discuss and attempt to analyse here is the monks' own self-presentation. The method chosen offered only limited insight into how the wider public was receiving this presentation-although in fact, this is an artefact of the monks' strategy, in which outreach primarily took the form of broadcasting and sharing recordings, with direct conversation involving the wider public limited in scope.

I look at the ways in which the monks' response identified particular needs in a time of social distancing, and how the community offered insight from the Benedictine experience that emphasized the relevance of monastic ways of living for contemporary society. I go on to consider some of the difficulties monks themselves faced during lockdown, and how these difficulties became ways of connecting their own lives with wider human experiences; at the same time the expansion of internet use and social media involvement can itself become a source of difficulty and harm for the monastic vocation (Jonveaux 2013, 2019). I conclude by arguing that the circumstances of the pandemic have generated new forms of proximity between monastic and lay life, reconfiguring the relationship between the monk 
as apparent "virtuoso" and a wider society who suddenly find themselves in a situation of solitude and separation from ordinary life.

\section{Absent Brethren}

On the 20th March, the Catholic church in England and Wales suspended all public church services as part of the effort to prevent the spread of COVID-19. While it was hoped at first that churches might remain open for private prayer, by the following week this too was deemed impossible in the wake of the UK lockdown measures.

For the monks of Downside Abbey, an English Benedictine community in the southwest of England, these announcements were uncharted territory. The sense of "weirdness" was a constant refrain in the monks' attempts to articulate life after they were required to shut their doors. As explained in a YouTube video recorded on the morning of the last public Mass until further notice, there was an "odd feeling"; one that was only to grow in intensity as the monks found themselves surrounded by absence due to the relative emptiness of the church. This absence was also marked by the lack of guests in the monastery's east wing, marking a suspension of the usual forms of hospitality that are part of the constitution of Benedictine life (Seasoltz 1974; Fortin 2003). A monastery's guest wing or guest house is a key point of contact between monks and the wider public who seek out the monastery as a place of retreat, prayer, and spiritual guidance (Pryce 2017); given that Chapter 53 of Rule of St Benedict, which the monks live by, states that a monastery is "never without guests", and indeed that guests are to be welcomed "as Christ", such emptiness is indeed a gap in the organisation of Benedictine monastic life.

In conversation with one of the monks over the telephone-it turned out that I was one of quite a few people who had taken the opportunity to phone him up after not being in touch for a while-we discussed how he had experienced the shift away from public services to the celebration of the liturgy behind closed doors. He described the new meaning which a particular liturgical element had taken on: most services in the Liturgy of the Hours-the occasions of prayer that structure the monastic horarium, or daily timetable - end with the prayer and response "May God's help be with us always"; "And with our absent brethren. Amen". Usually, this is understood as a reference to other monks in the community who are elsewhere for whatever reason; but in the context of lockdown, the reference to 'absent brethren' calls to mind all the people who cannot be there, or indeed in any church, and instead must stay at home. There was a renewed sense of the incompleteness of the community at prayer in the context of the pandemic (see also Johnson 2020, p. 209); those who gather together in a single location are only ever a fragment of the Church at prayer, and the emptiness of the church generated an acute consciousness of this fragmentation.

There was also concern for how troubling the closure of the churches must be to Catholic laypeople, and in particular, those in the parishes the monks serve and those who come to the Abbey Church. Given the centrality of weekly Communion in Catholic life, the inability to attend Mass on Sunday has been accompanied by a particular sense of loss (see also Abellanosa 2020) and concern. For this reason, the most immediate public response from the monks to the circumstances aimed to reassure Catholics that they would not be incurring sin through their inability to attend Mass at this time, explaining that the faithful can join in spiritual communion from home (see Foley 2021) - I was told that this was seen as an important statement in response to direct queries from concerned congregants in the parishes run by the monks. The monks provided advice (including links to web resources) on how to keep active in prayer, how to follow the readings of the services, and to participate remotely by watching Mass live-streamed from churchesalthough the monastery did not itself have the capacity to livestream the community Mass or other liturgical services from within the Abbey Church itself due to the lack of wifi there. Nevertheless, given the nature of Catholic sacramental life as embodied experience, there was a recognition that something would be missed in the immateriality of online involvement (notwithstanding the point, as made by Chow and Kurlberg (2020) that the 
digital is itself inherently material); the online could only ever be a limited, if important, substitute.

Crucially, there was recognition of the painfulness of isolation. Given the role of the church as a point of social connection to others, the loss of this opportunity for people to come together could be a source of loneliness, and indeed a danger to mental health (VanderWeele 2020). Here the online environment offered the monks an opportunity to share and put into practice key insights from their own lives that were of value in a time of lockdown. A central lesson that the monks took from their own life as Benedictines was that separation from the world without the structure of community life and social contact was dangerous. For this reason, as one of the monks explained in a "Thought for the Day" video on the subject of social distancing, posted on YouTube, it is "important first of all to think of social distancing as physical distancing". Now, more than ever, we should not be distancing ourselves socially but finding ways to connect. This is because "we are social creatures"-it is just that that sociality now requires "a different format".

\section{United in Prayer at a Distance}

In common with many Benedictine communities (Jonveaux 2019), the monastery has a longer history of using the internet for the purposes of outreach; they established a website in 2002, and have had a social media presence since 2015, when they joined Facebook, Twitter, and Instagram, primarily using these platforms to share a weekly link to the homily from Sunday Mass, as well as occasional news. However, the circumstances of lockdown and the requirement to close the churches led to a conscious decision by the community to intensify this social media activity and to increase the quantity and range of the material available as a means of connecting with people while they cannot be physically present. The pandemic has therefore accelerated pre-existing digital experimentation ( $\left.\mathrm{O}^{\prime} \mathrm{Brien} 2020\right)$, shifting the monastic community from sporadic weekly posts to daily engagement across social media and the creation of specific new content for social media audiences.

The primary means by which the community tries to create a sense of connection in prayer has been through the sharing of the liturgy. As was explained on the monastery's website, "It will be a different experience for all of us, but we hope we can feel united in prayer even at a distance". Since the lockdown began, recordings of Mass from the Abbey Church have been uploaded onto Soundcloud every day. In addition, sharing (even partially) in the prayer of the Liturgy of the Hours, which forms the basis of the monks daily timetable, has been encouraged as something which gives structure to time. In a YouTube video filmed in the choir stalls, one of the monks explained that the Liturgy of the Hours, normally associated with Priests and Monks, might be of particular value to laypeople at this moment as "a way of dividing and consecrating the day", while also "giving us a real sense of being connected with others because everyone is praying the same thing".

Praying with and for one another is "the reminder that we're not alone". In particular, during this time of lockdown, the homilies and bidding prayers repeatedly stressed that we are not alone, even in times of suffering-even, poignantly, remembering in prayer those who may be dying on their own as a way of being alongside them. A central theme in the material shared via social media is the acknowledgement of physical absence, while at the same time recognising that this sense of separation is misleading as long as we remember that we are united in prayer. This was clearly expressed in the Good Friday homily uploaded onto Soundcloud: "True, our churches are empty, but the Church, the people of God, are with us ... They are with us in spirit, and in the bond of prayer, and within the communion of the whole Church".

Yet while this emphasis on being united in prayer was an important part of the monastic community's rationale, the chosen forms of outreach left the audience as largely passive recipients, rather than an active presence. Such a relationship between monks and a wider public as passive listeners could in fact be seen to reflect the experience of attending services within the Abbey Church in ordinary, non-pandemic times: there is 
spatial separation between the monks, seated in the choir stalls and facing one another, and the lay congregation seated in the nave. Yet within the physical environment of the monastery, the spatial separation is nevertheless a structured involvement (see Irvine 2011, p. 43), enabling participation in the chanting of psalms, sharing of bodily gestures, and immersion in the sensory environment. The further separation of the listener from the monks chanting is therefore an intensification of the dynamic of separation of monks and laity, with a qualitative change in the nature of the involvement it structures.

Recordings of services shared for people to listen to after the fact establish the mode of communication as one-directional, while limiting the possibility for the audience to connect with one another. The number of listeners for daily services on Soundcloud during the lockdown typically ranged from 70 to 150 , but the identity of those listening largely remained unknown to the monks. While sharing links to these recordings on social media allowed listeners to reply, and each service typically attracted a small number of comments (typically thanks) across the social media platforms, the monk responsible for uploading and posting generally entered into conversation only to answer specific questions (as discussed later on, he felt it was important not to become "swallowed up" by social media). Ben-Lulu (forthcoming), describing Jewish prayer services during lockdown, notes that different modes of "online prayer" create very different dynamics, reflecting distinct priorities; those who chose to host live ceremonies on zoom emphasised real time participation and active community presence as core to prayer, while others prioritized the sanctity of the uninterrupted ritual by pre-recording, but this rendered the participants passive. Such choices (argues Ben-Lulu, forthcoming, p. 15) "affect how the congregants experience the service and, therefore, how the congregants experience their religion and, arguably, their relationship with God". Therefore, though the monks explained their outreach as a means of connecting with a wider audience, the fact that this took the form primarily of pre-recordings meant that such connection involved giving people the opportunity to listen to, rather than more actively engage with, prayer and teaching in the monastery. When occasional live broadcasts took place, with people being able to ask questions or make comments in the live chat, the emphasis was again placed on the monks sharing with a wider public, rather than building a live community interacting with one another.

In the monks' use of media, it is important to be attentive to the ways in which these can challenge traditional modes of authority and the ways in which the monks respond to this challenge. Hoover (2011) remarks that in the contemporary media landscape, control over symbols becomes a site of struggle; not only do traditional religious authorities find that they lose the exclusive right to deploy and interpret their core symbols, but they also find themselves engaging in forms of interaction that assume a "global media marketplace of symbolism" (Hoover 2011, p. 620), tacitly casting culture and identity as matters of individual choice. Here, the primarily unidirectional quality of the monastic outreach takes on particular significance, reflecting the "idea that religions can and should take control of their own stories" (Hoover 2011, p. 618); the chosen mode of media engagement here firmly retains the monastery as a locus of authority to be listened to. The wider public's participation, then, is as listeners; the invitation is to make themselves open to hear the chanting and teaching. Yet, crucially, when the monks shared the liturgy, this was with an invitation to "make it your prayer", with the clear idea that the listener was not only a recipient but also a participant in the act of worship.

In addition, while the use of technology was justified as a means of generating a sense of connection during a period of isolation, it is important to note that such means are not accessible to all. One of the monks explained to me that some of his most elderly parishioners do not have social media accounts or in some cases, the technical means to access them, and have difficulties with the interfaces for either recordings from the monastery or livestreams from elsewhere. As Seifert (2020, p. 674) has argued, older adults can find themselves particularly isolated: "Nonparticipation in the digital world could lead to a doubled feeling of social exclusion in times of physical distancing". Given that 
elderly parishioners can be among the most isolated and most reliant on the church for their sense of community, there is a particular danger not only that they have lost a focal point of real-life interaction but may also now be feeling left out of the new means of communication; as a result, the monk who highlighted this problem to me says that he is spending more time than ever on the phone.

\section{Sharing the Monastic Experience}

As noted above, the core of the monks' offerings online has been liturgical; daily recordings of the Mass were made available on Soundcloud and linked from the various social media accounts, along with more occasional recordings of other services in the monks' Liturgy of the Hours. The decision to upload only some of the Liturgy of the Hours was made partly for the reason that there is a lot of repetition between services, but also so as not to over impose the need for technological engagement on the community, and so the monk deploying the Tascam Recorder, editing the recordings on Audacity, and then uploading them on Soundcloud, did not have too much to do in addition to his other duties. As the monk who had taken on this responsibility explained to me in an email, "In the end, it is a judgement call; what can we reasonably do? What will people want to hear?".

Especially in the early period of lockdown, social media posts linking to the recordings on Soundcloud highlighted the benefits of the monks' chanting for general wellbeing; for example, "Feeling a little bit stressed and suffering from cabin fever? Listen to the plainchant from today's Mass" (in response, one listener thanked the monks and informed them he had made their recording of Compline, the final service of the monastic horarium, his bedtime listening). One of the recognised aspects of sharing services in this way was their expanded reach; as Chow and Kurlberg (2020) note, there is potential here for religious services to reach many more people, from a much wider geography, than would be the case if they were available only to those in physical reach (the fact that listeners are engaging with the services asynchronously, at a time of their choosing, further expands this audience; although as highlighted above, given that they can only engage asynchronously, such engagement is predicated on the fact that the audience remain individual listeners rather than forming a simultaneous or interactive community). This evangelistic potential to reach new audiences, including those who might not previously have engaged with Catholic liturgy or monastic chant, is hinted at by an emphasis on general wellbeing, and the suggestion that the liturgy might ease anxiety during lockdown; however, the monks did not engage in any wider marketing or promotion of content (for example by 'promoting' tweets) or deliberate strategies to expand their follower numbers other than through the more frequent posting of content.

While commercial recordings of chant have long brought the monastic experience into people's homes (Haste 2014) and are a source of income and reputation for some monastic communities, it has been striking that the community's monastic outreach has largely eschewed such professional production values. Instead, the monks' social media activity reflected the reality that sometimes the chanting can go a bit awry; as they announced on Twitter one morning: "The monks sound a bit ropey in this at times-such is life!" What's worth noting here is the way the community emphasises co-presence in the ordinary experience of the Abbey Church, even if that means listening to mistakes occasionally. In this, there's a sense of being part of the everyday routine of the community, "warts and all" (in the words of one of the monks) that accentuates the human connection. This also comes across in jokes when the technology fails, as happened on Easter Morning leading to the Twitter post: "The battery died during the Our Father and, unlike the Lord, would not resurrect, so the recording stops there".

This engagement has been characterised by experimentation to find creative and effective solutions in a novel and rapidly changing situation. Madianou and Miller (2012) offer a general theory of polymedia, in which users choose different forms of communication, each with different registers, on account of the medium's qualities and affordances. However, as the monks have worked across a broad range of available social media, their approach 
has been primarily adaptive and pragmatic, shifting between different platforms to find the most technically effective and user-friendly solution; for example, an attempt to live stream a Q\&A session failed to broadcast on Facebook, only for the monks to successfully switch it over to Instagram. Subsequently, a live Bible Study and a Healing Service were simultaneously broadcast on YouTube and Instagram (again, technical difficulties with the Wi-Fi led to them having to find a desktop computer with connectivity; you can hear the sound of the fan from the computer in the background-a humming, though not a particularly distracting one-suggesting it had not been used in a little while).

The community envisaged engaging with a number of different audiences through this outreach. One goal has been to find new ways of keeping in touch with parishioners and other people who might, in different circumstances, have attended services at the Abbey Church. Beyond this, social media has provided a means of partially compensating for the loss of monastic hospitality.

It cannot be denied that in the digital remediation of the liturgy, there is a loss of the tactile and physical experience of religion: what Parish (2020) terms the material absence of physical presence, leaving a sense of lack at the heart of digitally mediated religious practice. Such absence is reinforced by the fact that the liturgical ritual of the monastery is shared only in the form of sound recordings, stripping these occasions of prayer of their spatial context. Yet again, this is but one of a range of approaches the monks have experimented with, and indeed other dimensions of the monks' polymedia use appear to try and address this lack. Where the community have used their platforms to put up resources for virtual visitors-especially "thoughts for the day", explanations of the liturgy, and other videos-the physical environment of the monastery is deliberately employed (for example using particular artwork from around the Abbey church; or setting up the camera for YouTube videos in the choir stalls, the sacristy, or the room where the Novices and Junior monks receive their lessons). These uses of the monastery environment serve not only as illustration for the videos, but also perform an important purpose in creating a sense of "being there", involving people in place precisely at the time when they are excluded from it (see also Johnson 2020, p. 200) on the way that sense of place in digital religious outreach makes possible continuity of community in the face of physical separation).

Another central initiative here was the idea of a "virtual retreat". The monks usually host a large number of people for a retreat in the days leading up to Easter and the absence of these guests during this time of the liturgical year was particularly keenly felt. Yet, using their online platforms, the community argued that the inability of people to travel to the monastery due to lockdown did not necessarily mean they could not go on retreat. Indeed, the monks pointed out that they themselves make their annual retreat at home, which is precisely what everybody having to stay at home now has the opportunity to do: "If we can do it, so can you". This virtual retreat consisted of a number of live streamed and recorded talks, recordings of chant and readings from the services, and an encouragement to share in prayer, treating the time people are forced to be at home as an opportunity to "be on retreat" together.

The community are aware of the potential of social media to bring the materials they produce to completely new audiences. As one monk remarked in a telephone interview about the experiences of lockdown, "the world is now our congregation ... a somewhat terrifying thought". Digital media provide the opportunity for religious groups to build communities that expand beyond specific localities (Hutchings 2017), and in the context of the pandemic there has been a clear missional role for such digital outreach (Chow and Kurlberg 2020). The monks at Downside responded to this challenge in a particular way by arguing that monks have something particular to offer that a wider public could find valuable. Everyone has had to adapt to lockdown, but for monks there is a sense that they have the benefit of having been trained for these kinds of circumstances; that they have a certain expertise in "social distancing".

One of the goals of the monastery's output has been to share some elements of this insight. In a telephone interview, one of the monks involved in producing videos for 
YouTube explained the process of reflection that led to him recording advice on how to handle lockdown: "When people are at home and unable to leave when they like or to meet people, they start asking themselves, what do you do with all that time?" It is precisely here that the monks argue that the Rule of St Benedict has valuable lessons to teach. As was explained in the YouTube video on lessons from monastic life for social distancing: "It might be tempting to stay in bed all morning if you have nothing particular to get up for, or so it seems. But actually, in the long run you'll probably find that you feel much worse". The pattern of monastic living is one of structured time, a structure which emphasises "the right amount of sleep, food, prayer, work" and moderation in all things- "try not to be obsessive, but do a bit of everything that is important", and have regularity in doing it (significantly, another of these 'thought for the day' videos stresses the indispensable nature of recreation as part of this routine).

In considering the place of monks as those who transcend the world, Weber (1963) describes them as religious virtuosi, with the capacity to dedicate themselves to religious practice in ways that are out of reach of ordinary members of society. It is precisely this capacity that leads laypeople to seek them out for their spiritual capabilities. Yet strikingly, the form of virtuosity presented here is one that is characterised not by its exceptionalism, but by its relevance to universal human challenges and the difficulties of the moment. The monk, if seen as religious virtuoso, is usually taken to be one who cultivates their expertise partly through separation and isolation from the secular world (Weber 1963, pp. 162-63); but a moment when all of society is experiencing such separation and isolation provides the monks with an opportunity to encourage others to share in the very experience that is usually taken to set them apart.

A key element of the Rule is its emphasis on community; as was explained to me, Benedictines "have a special charism of community living and tending to others". Placing this emphasis on community was timely; some families have to get used to being in close quarters all day when they are not used to it, "wives driven mad by having to be at home with their husbands". In these contexts, the advice of the Rule in learning to have patience with the rest of your household may have value for all families. Meanwhile, the lockdown leaves many others on their own, and the monks set out the case that it is more important than ever to structure our lives in ways that allow for social contact in spite of separation: "now these are times when we can do great things for others; a smile, a telephone call, a message", keeping to the routine of meeting up for others for a coffee and a chat, even if it's over Zoom. Through this kind of advice, the monks attempt to draw from their own life and Rule lessons in the importance of community for self-isolators.

One talk uploaded onto YouTube, aiming to set out the relevance of the Rule of St Benedict in our current circumstances, highlights the word with which the Rule starts: "Listen". As the monk recording the video explains, "as we live through these difficult days, we're all being asked to listen with our hearts and show compassion towards our brothers and sisters in our home, and our neighbour". The idea of attentive listening is a central characteristic of daily life in the monastery (Irvine 2010, pp. 230-32): the monks listen to books (both sacred and secular) read aloud while they eat in silence; and of course, in their liturgy monks encounter the psalms verse by verse by listening and chanting alternately. Accordingly, the monastery has been described by some Benedictine scholars as a "community of listeners" (see Foster 2021). The invitation to attentive listening, therefore, is an invitation to a particular understanding of Benedictine spirituality and community-building.

We have discussed above the way in which the form of outreach chosen by the community might be seen to render the audience passive listeners; it is therefore striking to see listening recast here. As a response to isolation, listening is presented as an active means of connection; listening to God, listening to those around us even if we are physically distanced from them, and even (as a different video suggests) listening to "the birds that maybe you couldn't hear before because of all the traffic". 


\section{Despondency and Distraction}

During the homily on the feast of Pentecost-uploaded, as had become routine by this stage, onto SoundCloud and linked from the monastery's social media-the Prior described his view from the choir stalls. Through a grille opposite, he could see the silhouette of a life-size statue of Jesus and His Sacred Heart. In a church without a congregation and emptied of guests since the lockdown began, the sudden sense of a person looking in at you is uncanny. It appears as though someone is "standing, staring through the window". For the Prior, this statue had become somewhat symbolic of the feeling of social distance due to the measures to mitigate the spread of COVID-19. His faith that he is not alone, that Christ is present, and that the congregation at home are nevertheless with them in prayer, does not override the pain of separation at this time. "The statue, from a distance, looks a bit despondent, lonely, and isolated".

A key theme in the monks' social media outreach has been reflecting on this condition of isolation and its dangers. The sense of being cut off from everyday contact and feeling that you are missing out on life is understood as a danger to people's health (see also VanderWeele 2020). As expressed in a healing service live-streamed on Instagram and YouTube-a structured, non-liturgical set of prayers led by one of the monks of the community with an emphasis on asking God to heal those suffering from physical and mental illbeing-our relationships are an important part of us, and "the lost art of relationship" is a source of "inner wounds". Lockdown exacerbates this problem, leaving us to our own devices in a way that can foment a dangerous individualism.

In the absence of a connection, there is a risk of self-absorption, the monks warn: we can become wrapped up in ourselves and our own emotions. Our confinement can also leave us turning over painful memories and past wrongs, "hearts torn by past events that the evil one freshens in our mind from time to time". Hence, in much of the content they uploaded, the monks draw on their Benedictine history and experience of cenobitic life - that is living, eating, and praying together-to emphasise the importance of finding ways to keep the social impulse alive, maintaining regular contact with friends, family, and community. As stated in the healing service, "to start on the process of recovery, look out to see if there are others you might serve".

In acknowledging isolation and despondency, monks recognise that this struggle is something they also face in their lives, especially at this time. One monk of the community, currently teaching in Rome, described to me the sharp shifts in emotion as Italy struggled with the first wave of COVID-19 infection. The sudden decision to close places of learning felt almost like an unexpected holiday; excitement that was quickly engulfed by fear and uncertainty about the situation, anxiety of risk from the infection, and grief amidst the rising death toll. Then lockdown. "Now, inevitably, it has begun to shift to a kind of stale boredom. Cassian, of course, had just the word for it-acedia. Yesterday I just went to the end of the drive, simply to look outside and enjoy (really enjoy) the sight of the wisteria in the road. That is the real pity-to miss the spring colours and smells".

His words captured the feeling of constraint, even within the monastery grounds; though monks recognise self-isolation as a feature of their lives on which they might share expertise, life for Benedictines is nevertheless not typically one of total confinement to the enclosure. Yet, in recognising and naming the "stale boredom" as acedia, what was striking was the way in which he reached back into the history of the monastic experience. John Cassian, born around 360AD, compiled and digested the teachings of those "desert monks" who had withdrawn from society to live lives of prayer on the Nile Delta. In his Institutes, he describes the dejection and weariness that was a frequent foe of the monks, and was denoted by the Greek word 'acedia'; the word itself can be translated as "lack of care" (see (Nault 2015) for a contemporary Benedictine commentary on acedia). Another term the desert monks used for acedia was "the midday demon", identifying the sense of torpor and dejection monks experienced at noon when the sun seemed to stand still and time refused to pass-a description that resonates with the sluggishness of time in lockdown. 
Here, the recognition of acedia identified the state of boredom during lockdown as a universal site of spiritual struggle (Irvine 2020). It offers companionship from history for those experiencing what was described in one healing service as "despondency and a sense of aimlessness, constrained as they are sometimes in very tight conditions", dejected by circumstances that "seem, as it were, to be indefinite as well as unlimited". In isolation, such a struggle is hard, and it is against the backdrop of the solitary struggle of the desert monks that Benedictines understand the history of their structure and organisation, as a way of managing the struggle. It is with this in mind that we can understand the way the Benedictine monks in their outreach draw on lessons from their own life and rule, seeing it as offering an important insight for a time of lockdown. The development of the cenobitical way of life (eating and praying together) is understood as a response to the challenges of early monks' individual struggles, recognising the need to support one another; the importance of a shared timetable as a discipline against the restlessness of boredom.

One of the dangers the monks recognise in this state of despondency-and here again they point to insights from monastic history-is the tendency to seek distractions. This concern was addressed in the first livestreamed Q\&A during lockdown: "if we are talking about being bored with a job, or aspects of life well, that is life! Religious life is real life and sometimes we have to get on with it". In which case, are we equipped to deal with boredom, or do we turn to means of escape? It is, of course, an irony recognised by the monastic community that social media can easily become precisely this kind of distraction. It falls into a category described by one of the monks as "things which, good in themselves, can have a power over us simply because they've got out of proportion"; putting them first, we make ourselves "less available to God's love". As Jonveaux (2019) points out, immersion in digital worlds has the potential to undermine stability and monastic enclosure and can lead to a tension between the individual and the community; while from her own experience of Benedictine monastic outreach Wybourne (2020, p. 47) notes the danger of self-indulgence, "cultivating a personal following at the expense of the community project".

The context of the Benedictine vow of stability is important here; a strictly locative definition of stability (to remain within the monastery) is well served by a mode of outreach that allows the community to engage with a wider, potentially global public, without having to leave the enclosure. Yet as Polan (2018) points out, there is another fundamental sense of stability as commitment to the community and "witness to interdependence among one another" (Polan 2018, p. 234). It is here that monks find themselves needing to safeguard against the potential individualizing effect of social media, and in particular its potential to draw monks away from social interaction within the community and towards their devices. In as much as communication technology has become a necessary feature of contemporary Benedictine work and outreach it presents new challenges to stability, with the potential of distraction from the daily horarium, even in the act of presenting that horarium to the world. Means of recording and broadcast have accordingly been chosen with a minimally intrusive approach in mind; yet the recognition of a wider audience recalibrates prayer and teaching shared with a small group in ways that have the risk of undermining the vow of stability's focus on the community itself.

Given the danger that lockdown will lead to loneliness and isolation, the ability to create co-presence and build connections through social media has been considered invaluable. It has enabled people to listen to the liturgy who would not otherwise have been able to-indeed, the monks view this as an opportunity for participation in the prayer of the community, albeit this is a passive form of participation, as we have noted aboveand it has created opportunities for learning and teaching that would not otherwise have been possible. Yet as was made clear in a Q\&A session livestreamed by the monks in May 2020, "in one sense there have been blessings. I think we have to say they've come at a price". The connectivity of the monks at this time has been one of these blessings, creating new forms of outreach that would not have been possible and involving people "to the ends of the earth". At the same time, such an outreach risks binding people to what one monk termed "the servitude of the screen". This was reflected in the comments of the 
monk responsible for recording, uploading, and sharing services: there are opportunities to build new forms of community through online tools, and moreover this can be fun- "I quite enjoy doing this!". At the same time, he recognises the need for balance, both for the community as a whole and for himself: "I also need to avoid being swallowed up by social media!".

\section{Conclusions: Separation as a Point of Connection}

In the face of tremendous human suffering, the shift of religious practice online has been an act of care (VanderWeele 2020) and an expression of solidarity: "no one should suffer alone... the church is still present as one family, although the medium has shifted to digital media" (Chu 2021, p. 28). The experience of pain and loss is one that is shared by the monks, and their outreach during the pandemic is grounded in a common reality of suffering. The consciousness of separation from "absent brethren" and of despondency in the face of lockdown connects the monks lives with the anxieties of wider society, while expressing those anxieties in language shaped by the culture and history of Christian monasticism.

This study points towards a number of key analytical considerations for future scholarship on the ways that religious communities engage with digital religion. Firstly, how the choice of media shapes a particular relationship - in this case, that relationship is a primarily unidirectional one in which the monastery remains the locus of authority, but also, interestingly, in which listening is explicitly cast as a form of active participation. While listening at a distance is indeed the only possible approach one can take to the digitally-mediated prayer of the monks, this is framed in the context of a Benedictine sensibility in which attentive listening is a key element of monastic living. Secondly, it opens up an analysis of the role of social media as both a potential benefit and source of harm to the life of a religious community; and in the Benedictine setting we see in particular the question of how digital outreach interfaces with the vow of stability. Yet the context of this outreach in pandemic times also forces our attention towards the very particular circumstances of isolation and the ways in which religious communities can recognise and seek to provide resources for that isolation-while crucially recasting that isolation as an opportunity for spiritual growth. In the case discussed here, what is striking is the way that monks are able to present lockdown as a challenge that can be met with a specifically monastic spirituality.

Recognising that the need to adapt rapidly to circumstances of crisis has created a space for novel experiments and innovation ( $\mathrm{O}^{\prime}$ Brien 2020), I have examined the intensification of the monks' online presence as a response to the challenge of isolation, while exploring the potential of this outreach to reach new audiences and generate communityalbeit a community constituted through passive and individual engagement with the monks' broadcasts. Significantly, the challenge of lockdown provides common ground within which the monks can teach from experience-both their own personal experience, and the historic experience of the Benedictine life and rule. A life of structured social distancing means they are able to offer something of value to those having to adapt to the challenge of self-isolation; this becomes a point of invitation to wider society. Here, characteristically, English Benedictines engage in the performance of proximity (Irvine 2017), placing emphasis on continuities between the monastery and the world beyond, rather than laying claim to exceptionalism.

As apparent experts in social distancing, the monks are able to speak from a distinctive position of relevance to contemporary life. At the same time, their emphasis on the common experience of isolation at this moment invites the wider public to engage with a monastic understanding of the world. While Weber (1963) depicts the monk as worldtranscending "virtuoso", what is remarkable here is that a key element of the monks' virtuosity - their separation from the world-is offered as a point of connection with the world in pandemic times. 
Funding: This research received no external funding.

Institutional Review Board Statement: Ethical approval was granted for this study (approval code SA14883) by the School of Philosophical, Anthropological and Film Studies Ethics Committee, acting on behalf of the University of St Andrews Teaching and Research Ethics Committee.

Informed Consent Statement: Informed consent was obtained from all research participants.

Conflicts of Interest: The author declares no conflict of interest.

\section{References}

Abellanosa, Rhoderick John Suarez. 2020. The Church as a Sacrament in a Time of Pandemic: The Philippine Experience. Studies in World Christianity 26: 261-80. [CrossRef]

Alyanak, Oğuz. 2020. Faith, Politics and the COVID-19 Pandemic: The Turkish Response. Medical Anthropology 39: 374-75. [CrossRef]

Baker, Joseph O., Gerardo Martí, Ruth Braunstein, Andrew L. Whitehead, and Grace Yukich. 2020. Religion in the Age of Social Distancing: How COVID-19 Presents New Directions for Research. Sociology of Religion 81: 357-70. [CrossRef]

Ben-Lulu, Elazar. Forthcoming. Zooming In and Out of Virtual Jewish Prayer Services During the COVID-19 Pandemic. Journal for the Scientific Study of Religion.

Campbell, Heidi A. 2010. When Religion Meets New Media. Abingdon: Routledge.

Cavaliere, Paola. 2021. Religious Institutions in Japan Responding to Covid-19-Induced Risk and Uncertainty. Journal of Religion in Japan 10: 31-63. [CrossRef]

Chow, Alexander, and Jonas Kurlberg. 2020. Two or Three Gathered Online: Asian and European responses to COVID-19 and the Digital Church. Studies in World Christianity 26: 298-318. [CrossRef]

Chu, Calida. 2021. Theology of the pain of God in the era of COVID-19: The reflections on sufferings by three Hong Kong churches through online services. Practical Theology 14: 22-34. [CrossRef]

Foley, Edward. 2021. Spiritual Communion in a Digital Age: A Roman Catholic Dilemma and Tradition. Religions 12: 245. [CrossRef]

Fortin, John R. 2003. The Reaffirmation of Monastic Hospitality. Downside Review 121: 105-18. [CrossRef]

Foster, David. 2021. Lectio Divina: Reading in The Rule of St Benedict. CounterText 7: 30-45. [CrossRef]

Frederick, Marla. 2020. COVID-19, Religious Markets, and the Black Church. Religion and Society 11: 186-92. [CrossRef]

Goldman, Marion, and Steven Pfaff. 2014. Reconsidering Virtuosity: Religious Innovation and Spiritual Privilege. Sociological Theory 32: 128-46. [CrossRef]

Haste, Amanda J. 2014. Buying into the Monastic Experience: Are Chant Recordings the Real Thing? In The Paradox of Authenticity in a Globalised World. Edited by Russell Cobb. New York: Palgrave Macmillan, pp. 69-84.

Hoover, Stewart M. 2011. Media and the imagination of religion in contemporary global culture. European Journal of Cultural Studies 14: 610-25. [CrossRef]

Hutchings, Tim. 2017. Creating Church Online: Ritual, Community and New Media. Abingdon: Routledge.

Irvine, Richard D.G. 2010. The experience of ethnographic fieldwork in an English Benedictine monastery: Or, not playing at being a monk. Fieldwork in Religion 5: 221-35. [CrossRef]

Irvine, Richard D. G. 2011. The Architecture of Stability: Monasteries and the Importance of Place in a World of Non-Places. Etnofoor 23: 29-49.

Irvine, Richard D. G. 2017. The everyday life of monks: English Benedictine identity and the performance of proximity. In Monasticism in Modern Times. Edited by Isabelle Jonveaux and Stefania Palmisano. London: Routledge, pp. 191-208.

Irvine, Richard D. G. 2020. This stale boredom: Acedia in a time of lockdown. Journal of Civic Architecture 3: 141-43.

Johnson, Sarah Kathleen. 2020. Online Communion, Christian Community, and Receptive Ecumenism: A Holy Week Ethnography during COVID-19. Studia Liturgica 50: 188-210. [CrossRef]

Jonveaux, Isabelle. 2013. Facebook as a monastic place? The new use of internet by Catholic monks. Scripta Instituti Donneriani Aboensis 25: 99-109. [CrossRef]

Jonveaux, Isabelle. 2019. Internet in the Monastery: Construction or Deconstruction of the Community? Online: Heidelberg Journal of Religions on the Internet 14: 61-78.

Kuipers, Nicholas, Saiful Mujani, and Thomas Pepinsky. Forthcoming. Encouraging Indonesians to Pray from Home During the COVID-19 Pandemic. Journal of Experimental Political Science, 1-12. [CrossRef]

Madianou, Mirca, and Daniel Miller. 2012. Polymedia: Towards a new theory of digital media in interpersonal communication. International Journal of Cultural Studies 16: 169-87. [CrossRef]

Nault, Jean-Charles. 2015. The Noonday Devil: Acedia, the Unnamed Evil of Our Times. Translated by Michael J. Miller. San Francisco: Ignatius Press.

Norman, Ziba, and Michael J. Reiss. 2020. Risk and Sacrament: Being Human in a COVID-19 World. Zygon 55: 577-90. [CrossRef]

O'Brien, Hazel. 2020. What does the rise of digital religion during COVID-19 tell us about religion's capacity to adapt? Irish Journal of Sociology 28: 242-46.

Parish, Helen. 2020. The Absence of Presence and the Presence of Absence: Social Distancing, Sacraments, and the Virtual Religious Community during the COVID-19 Pandemic. Religions 11: 276. [CrossRef] 
Polan, Gregory J. 2018. Spiritual value of the Benedictine vow of Stability. American Benedictine Review 69: 229-36.

Pryce, Paula. 2017. The Monk's Cell: Ritual and Knowledge in American Contemplative Christianity. New York: Oxford University Press. Rüpke, Jörg. 2016. Individualization and Privatization. In The Oxford Handbook of the Study of Religion. Edited by Michael Stausberg and Steven Engler. Oxford: Oxford University Press, pp. 702-17.

Seasoltz, R. Kevin. 1974. Monastic Hospitality. American Benedictine Review 25: 427-51.

Seifert, Alexander. 2020. The Digital Exclusion of Older Adults during the COVID-19 Pandemic. Journal of Gerontological Social Work 63: 674-76. [CrossRef]

Silber, Ilana Friedrich. 1995. Virtuosity, Charisma, and Social Order: A Comparative Sociological Study of Monasticism in Theravada Buddhism and Medieval Catholicism. Cambridge: Cambridge University Press.

VanderWeele, Tyler J. 2020. Love of Neighbor During a Pandemic: Navigating the Competing Goods of Religious Gatherings and Physical Health. Journal of Religion and Health 59: 2196-202. [CrossRef]

Weber, Max. 1963. The Sociology of Religion. Translated by Ephraim Fischoff. Boston: Beacon Press.

Weber, Max. 1968. Economy and Society: An Outline of Interpretive Sociology. Edited by Guenther Roth and Claus Wittich. Translated by Ephraim Fischoff, Hans Gerth, Alexander M. Henderson, Ferdinand Kolegar, Charles Wright Mills, Talcott Parsons, Max Rheinstein, Guenther Roth, Edward Shils, and Claus Wittich. New York: Bedminster.

Wybourne, Catherine. 2020. Being Benedictine Online. In The Distanced Church: Reflections on Doing Church Online. Edited by Heidi A. Campbell. College Station: Digital Religion Publications, pp. 46-47. 